Saptadi, D. • D. G. Cahyaningrum • N.R. Ardiarini • B. Waluyo

\title{
Stabilitas hasil dan adaptabilitas galur-galur harapan kacang Bogor di tiga lokasi
}

Sari Kacang Bogor (Vigna subterranea (L.) Verdcourt) potensial dikembangkan sebagai komoditi pangan rendah lemak. Pengembangan dan peningkatan hasil komoditas ini dapat dilakukan melalui penyediaan varietas unggul. Tujuan penelitian ini ialah untuk mengetahui stabilitas dan adaptabilitas hasil enam galur harapan kacang Bogor, yaitu GSG 2.1.1, GSG 2.5, GSG 1.5, CCC 1.4.1, PWBG 5.3.1, dan BBL 6.1.1. Penelitian dilakukan di tiga lokasi yang memiliki karakteristik ketinggian tempat, kondisi lahan, dan musim tanam berbeda. Percobaan menggunakan rancangan acak kelompok dengan tiga ulangan yang dilanjutkan dengan analisis varians gabungan. Analisis regresi digunakan untuk menentukan stabilitas dan adaptabilitas hasil berdasarkan Eberhart-Russell dan Finlay-Wilkinson. Hasil penelitian menunjukkan terdapat interaksi genotipe $x$ lingkungan pada bobot hasil panen polong segar dan bobot hasil biji kering. Galur GSG 2.5 dan CCC 1.4.1 mempunyai hasil polong segar dengan rata-rata 15,50 $\mathrm{t} \mathrm{ha}^{-1}$ dan 15,71 $\mathrm{tha}^{-1}$ dan hasil biji kering dengan rata-rata $4,58 \mathrm{t} \mathrm{ha}^{-1}$ dan 4,57 t.ha $^{-1}$ yang stabil dan beradaptasi luas. Galur GSG 1.5 dan BBL 6.1.1 merupakan galur yang mempunyai potensi hasil tinggi untuk polong segar dengan rata-rata 17,16 t ha- ${ }^{-1}$ dan 18,90 t.ha $^{-1}$ pada lingkungan yang produktif.

Kata kunci: Interaksi G x E · Kacang Bogor · Pemuliaan tanaman · Stabilitas hasil · Uji adaptasi

\section{Yield stability and adaptability of bambara groundnut promising lines in three locations}

\begin{abstract}
The bambara groundnut (Vigna subterranea (L.) Verdcourt) has the potential to become a low-fat food commodity. The development and improvement of this commodity yield can be accomplished through the introduction of superior varieties.

The study was carried out in three different locations with varying altitude, land type, and growing season. A randomized block design with three replications was implemented in the experiment, which was then followed by a combined analysis of variance. Regression analysis was used to determine the stability and adaptation of yield based on Eberhart-Russell and Finlay-Wilkinson. The results revealed that there was an interaction between genotypes and environments on yield of fresh pods weight and yield of dried seeds weight. Lines of GSG 2.5 and CCC 1.4.1 had fresh pod yields with an average of $15.50 \mathrm{tha}^{-1}$ and $15.71 \mathrm{t} \mathrm{ha}^{-1}$ and dry seed yields an average of $4.58 \mathrm{t} \mathrm{ha} \mathrm{A}^{-1}$ and $4.57 \mathrm{t}$ ha $^{-1}$ which is stable and wide adaptations. In an ideal environment, the GSG 1.5 and BBL 6.1.1 lines had high yield potential for fresh pods, with an average of $17.16 \mathrm{t} \mathrm{ha}^{-1}$ and $18.90 \mathrm{tha}^{-1}$.
\end{abstract}

Keywords: Adaptation test · Bambara groundnut . Gx E interaction · Plant breeding · Yield stability

Diterima : 26 Februari 2021, Disetujui : 5 Juni 2021, Dipublikasikan : 1 Agustus 2021

DOI: https://doi.org/10.24198/kultivasi.v20i2.32418

Saptadi, D. · D. G. Cahyaningrum · N.R. Ardiarini · B. Waluyo

1Laboratorium Pemuliaan Tanaman, Jurusan Budidaya Pertanian, Fakultas Pertanian, Universitas

Brawijaya, Jl. Veteran, Malang, 65145

Korespondensi: budiwaluyo@ub.ac.id 


\section{Pendahuluan}

Kacang Bogor (Vigna subterranea (L.) Verdcourt) sangat potensial untuk dikembangkan di Indonesia karena dapat dijadikan sebagai salah satu alternatif sumber pangan rendah lemak. Saat ini sebagian besar produksinya masih dimanfaatkan untuk camilan. Analisa biokimia terhadap kandungan karbohidrat, lemak, protein, dan mineral menunjukkan nilai diet yang seimbang. Kacang Bogor diketahui memiliki kandungan protein 19\% dan mengandung semua asam amino esensial serta serat diet $10 \%$, kandungan fraksi terlarut rendah dan kandungan lemak sebesar 1,4\%, dan proporsi lemak tak jenuh 61\% (Yao et al., 2015). Skor protein $80 \%$ jika dibandingkan dengan kacang tanah (65\%), kedelai (74\%), dan kacang tunggak (64\%) (Schaafsma, 2012). Kacang Bogor juga dikenal sebagai tanaman yang tahan ditanam pada lahan kering (Mabhaudhi and Modi, 2013; Muhammad et al., 2016).

Pengembangan kacang Bogor di Indonesia menghadapi beberapa kendala, diantaranya belum tersedianya varietas unggul. Varietas yang dibudidayakan petani adalah varietas lokal yang biasanya di dalam populasi mempunyai keragaman tinggi, umur panjang, dan produktivitas rendah (Rahmawati et al., 2016). Upaya pemuliaan tanaman perlu dilakukan guna menghasilkan varietas-varietas unggul berdaya hasil tinggi yang dapat beradaptasi secara luas di kondisi agroklimat Indonesia. Kacang Bogor adalah tanaman menyerbuk sendiri (Chijioke et al., 2010) sehingga cukup mudah untuk mendapatkan populasi yang memiliki komposisi genetik yang homozigot dan homogen. Underutilised Crop Research Center di Fakultas Pertanian Universitas Brawijaya telah melakukan upaya pemuliaan kacang Bogor yang dimulai dengan eksplorasi, koleksi, dan seleksi terhadap galur-galur yang dibudidayakan di Indonesia (Nuryati et al., 2014; Arif et al., 2016; Nugraha et al., 2017). Uji daya hasil pendahuluan terhadap 6 galur telah dilakukan dan didapatkan informasi bahwa daya hasil galur-galur terpilih tersebut relatif tinggi (Pratama dan Saptadi, 2017). Uji stabilitas hasil dan adaptabilitas perlu dilakukan untuk mengetahui seberapa layak galur-galur tersebut dikembangkan lebih lanjut menjadi varietas unggul. Acuan hasil panen pada kacang Bogor di petani ialah hasil panen polong segar yang biasanya dilanjutkan untuk diolah sebagai bahan baku industri makanan ringan, dan hasil biji kering yang biasanya digunakan sebagai bahan bahan baku industri tepung dan benih.

Penampilan suatu tanaman tidak sematamata dikendalikan oleh faktor genetik, tetapi juga oleh faktor lingkungan dan interaksi antara keduanya. Kegagalan suatu genotipe secara konsisten merespons kondisi lingkungan yang bervariasi disebut dengan interaksi genotipe lingkungan (GxE) (Nor and Cady, 1979). Stabilitas dan adaptabilitas suatu galur terhadap lingkungan yang beragam biasanya diuji dengan melihat derajat interaksinya pada lingkungan tumbuh yang berbeda (Finlay dan Wilkinson, 1963). Pengetahuan tentang interaksi genotipe dan lingkungan sangat berguna untuk meningkatkan efisiensi program pemuliaan dan seleksi untuk mendapatkan genotipe terbaik (Dolinassou et al., 2016). Suatu genotipe menunjukkan stabilitas yang statis apabila memiliki daya produktivitas yang sama pada berbagai lingkungan tumbuh, dan dikatakan memiliki stabilitas dinamis apabila daya adaptasinya mengikuti indeks lingkungan (Becker and Leon, 1988).

Informasi kemampuan potensi, adaptasi, dan stabilitas hasil dapat menggali keunggulan karakter dari ukuran metriks suatu genotipe dan menjadi dasar dari penilaian calon varietas sebagai salah satu syarat untuk pelepasan varietas di Indonesia. Analisis terhadap interaksi genotipe dengan lingkungan penting dilakukan untuk mengidentifikasi genotipe beradaptasi spesifik atau beradaptasi luas (Sabaghnia et al., 2012). Uji adaptasi kacangkacangan dan ubi-ubian dapat dilakukan pada lokasi sawah, tadah hujan, dan lahan kering (Syukur et al., 2012).

Metode regresi linier dari Finlay dan Wilkinson (1963) dan Eberhart dan Russell (1966) telah banyak digunakan untuk menguji stabilitas dan adaptabilitas pada banyak komoditi tanaman (Adie et al., 2013; Rahayu et al., 2013; Purwoko et al., 2014; Akmal et al., 2015). Kedua metode tersebut menggunakan parameter koefisien regresi (bi), simpangan regresi $\left(\mathrm{Sd}^{2}\right)$ suatu galur untuk menduga daya adaptasi dan stabilitas hasil. Hasil dari pengujian pada penelitian ini diharapkan memberikan informasi tentang stabilitas daya hasil dan kemampuan adaptasi galur-galur yang diuji di beberapa lingkungan tumbuh sehingga dapat diperoleh galur-galur harapan 
yang beradaptasi luas dan galur-galur yang beradaptasi secara sempit atau spesifik lingkungan.

\section{Bahan dan Metode}

Enam galur harapan kacang Bogor hasil pemuliaan tanaman di Underutilised Crops Research Centre, Fakultas Pertanian, Universitas Brawijaya yaitu GSG 2.1.1, GSG 2.5, GSG 1.5, CCC 1.4.1, PWBG 5.3.1, dan BBL 6.1.1 ditanam di tiga lokasi berbeda di Kabupaten Malang (Tabel 1). Percobaan pada tiap lokasi dilakukan berdasarkan Rancangan Acak Kelompok (RAK) diulang 3 kali. Plot percobaan berupa bedengan berukuran $0,7 \times 3,9 \mathrm{~m}$. Jarak tanam pada bedengan $0,30 \times 0,25 \mathrm{~m}$. Pemupukan pertama diberikan bersamaan dengan pengolahan lahan dengan pupuk kandang 1,5 ton ha-1, SP 36100 $\mathrm{kg} \mathrm{ha}^{-1}$, dan KCL $100 \mathrm{~kg} \mathrm{ha}^{-1}$. Pupuk Urea $50 \mathrm{~kg}$ ha $^{-1}$ diberikan 3 kali, yaitu pada saat tanam, pada saat tanaman berumur 21 hst, dan pada saat tanaman menjelang berbunga berumur 40 hst.

Pengamatan dilakukan pada penelitian ini ialah pada karakter hasil panen polong segar (ton ha-1) dan hasil panen biji kering (ton ha-1). Data hasil pengamatan dianalisis ragam berdasarkan rancangan acak kelompok pada masing-masing lokasi untuk mendeteksi ragam galat setiap unit percobaan. Uji dilanjutkan dengan uji homogenitas ragam galat di setiap unit percobaan menggunakan metode Bartlett dengan prinsip uji khi-kuadrat (Gomez \& Gomez, 1995) sebagai berikut:

$X^{2}=\frac{(2,3026)(f)\left(k \log s_{p}^{2}-\sum_{i=1}^{k} \log s_{i}^{2}\right)}{1+\left[\frac{[+1}{3 k j}\right]}$, untuk derajat

bebas $(k-1)$

di mana:

$\mathrm{k}=$ banyaknya ragam yang diuji; $\mathrm{f}=$ derajat bebas dari k-buah ragam yang diuji; $s_{p}^{2}=$ nilai ragam gabungan; $s_{i}^{2}=$ nilai ragam masingmasing lingkungan

Jika nilai ragam galat pada semua unit percobaan homogen, maka dilanjutkan dengan analisis ragam gabungan dari seluruh lokasi sehingga akan dihasilkan satu sumber ragam galat untuk melakukan analisis ragam gabungan masing-masing lokasi. Sumber ragam GxE yang memiliki nilai kuadrat tengah berbeda nyata pada nilai signifikansi 5\% dilanjutkan dengan uji perbedaan rata-rata antar galur dalam lokasi yang sama menggunakan uji Beda Nyata Jujur (BNJ) pada taraf nyata 5\%. Perbedaan respons galur terhadap lingkungan ditentukan berdasarkan pada stabilitas hasil dengan model regresi linier (Eberhart and Russell, 1966) dan adaptasi terhadap lingkungan dengan metode Finlay and Wilkinson (1963) melalui interpretasi sebagai berikut. Jika nilai koefisien regresi suatu galur (bi) tidak berbeda nyata dengan 1, dan nilai simpangan terhadap regresi $\left(\mathrm{Sd}^{2}\right)$ tidak berbeda nyata dengan 0 maka galur tersebut stabil, dan nilai $\mathrm{Sd}^{2}$ sama dengan nol dengan $\mathrm{b} i>1$ maka galur beradaptasi pada lingkungan produktif, jika bi $<1$ maka galur beradaptasi pada lingkungan marginal.

\section{Hasil dan Pembahasan}

Berdasarkan karakteristik lingkungan di 3 lokasi dan waktu penanaman yang berbeda, diperoleh keragaman lingkungan yang berbeda, baik dari jenis tanah, tekstur tanah, curah hujan, kelembaban udara relatif, dan kandungan bahan organik lahan tempat percobaan (Tabel 1). Perbedaan karakteristik lingkungan ini merupakan komponen yang dapat diduga dan komponen yang tidak dapat diduga (Allard and Bradshaw, 1964) yang secara statistika dapat dijadikan sebagai komponen sumber keragaman yang acak untuk penilaian stabilitas dan adaptabilitas (Annicchiarico et al., 2006) dari galur-galur harapan yang diuji.

Anova pada karakter hasil panen polong segar dan hasil panen biji kering di setiap lokasi menunjukkan adanya keragaman pada galur yang diuji. Uji homogenitas ragam galat pada karakter hasil panen polong segar dan hasil panen biji kering di tiga lokasi menunjukkan homogen. Hal ini menunjukkan bahwa galat dari data yang diperoleh di tiga lokasi tidak berbeda dan dapat dilakukan analisis ragam gabungan sehingga untuk pengujian penampilan dapat menggunakan satu sumber galat. Ragam galat gabungan digunakan untuk mendapatkan satu nilai galat pada serangkaian hasil penelitian yang melibatkan unit percobaan yang berbeda berkaitan dengan interaksi genotipe $\mathrm{x}$ lingkungan (LeClerg et al., 1966; Petersen, 1994; Annicchiarico, 2002). 
Hasil analisis ragam gabungan pada variabel hasil panen polong segar dan hasil biji kering menunjukkan bahwa lingkungan, genotype, dan interaksi genotipe lingkungan berkontribusi terhadap keragaman pada karakter yang diamati. Hal ini menunjukkan bahwa keragaman yang muncul pada karakter yang diukur adalah karena disebabkan oleh lokasi, galur, dan interaksi antara galur $x$ lokasi. Lingkungan adalah semua aspek yang mendukung pertumbuhan tanaman sehingga tanaman dapat memanfaatkan sumber daya di sekitarnya secara optimal yang dikonversi menjadi hasil. Interaksi $x$ genotipe yang nyata pada analisis ragam gabungan memungkinkan penelitian ini mengkaji kontribusi setiap komponen sumber ragam terhadap penampilan karakter pada setiap galur kacang Bogor yang diuji.

Keragaman pada karakter hasil bobot polong segar disebabkan oleh faktor lokasi sebesar $30,63 \%$, faktor genotipe sebesar $19,30 \%$, dan faktor interaksi genotipe $x$ lingkungan sebesar $34,36 \%$. Berdasarkan besaran proporsi ini dapat diketahui pengaruh interaksi genotipe $x$ lingkungan memberikan pengaruh terbesar terhadap keragaman karakter hasil bobot polong segar. Pada karakter hasil bobot biji kering, keragaman yang terjadi disebabkan oleh faktor lokasi sebesar $51,54 \%$, faktor genotipe $10,26 \%$, dan faktor interaksi genotipe $x$ lingkungan sebesar 26,63\% (Tabel 2). Hasil ini menunjukkan bahwa keragaman terbesar adalah akibat dari adanya variasi pada lingkungan, dalam hal ini lokasi dan interaksi genotipe $x$ lingkungan dibandingkan dengan faktor yang disebabkan oleh genotipe. Hal ini berpengaruh terhadap pengambilan keputusan dalam pengembangan kacang Bogor. Interaksi genotipe $\mathrm{x}$ lingkungan sangat berpengaruh terhadap pemilihan genotipe kacang Bogor pada tiga lokasi berbeda yang disebabkan faktor lingkungan yang berpengaruh, terdiri dari perbedaan curah hujan, temperatur, dan kesuburan tanah (Pungulani et al., 2012).

Urutan peringkat galur kacang Bogor berdasarkan hasil polong segar maupun biji kering menunjukkan perbedaan untuk tiap lokasi. Semua genotipe memiliki hasil yang rendah di lokasi Kromengan yang memiliki produktifitas lahan relatif rendah. Genotipe BBL 6.1.1 memiliki hasil polong segar tertinggi di semua lokasi. Lima dari enam genotipe meningkat hasilnya dengan meningkatnya tingkat kesuburan tanah (Gambar 1 dan 2). Perubahan peringkat suatu genotipe pada setiap lokasi uji menunjukkan adanya interaksi kualitatif sebagai suatu interaksi genotipe $x$ lingkungan (Baye et al., 2011). Interaksi genotipe $x$ lingkungan yang bersifat kualitatif menyebabkan seleksi genotipe sulit dilakukan karena satu genotipe hanya sesuai untuk lingkungan tertentu dan genotipe lain untuk lingkungan yang berbeda. Analisis stabilitas diperlukan pada kondisi ini untuk menentukan genotipe yang stabil pada berbagai lingkungan (Asad et al., 2009). Analisis stabilitas dapat secara efektif menguraikan pengaruh interaksi genotipe $x$ lingkungan sehingga genotipe-genotipe yang stabil dan spesifik dapat dipilah (Farshadfar et al., 2012).

Finlay dan Wilkinson (1963) menyatakan bahwa suatu genotipe dinyatakan stabil dengan daya adaptasi tinggi terhadap semua lingkungan apabila memiliki koefisien regresi $(b i)=1$ dan rataan hasil lebih tinggi dari rataan total. Eberhart dan Russell (1966) menyatakan suatu genotipe dinyatakan stabil apabila memiliki nilai koefisien regresi (bi) mendekati 1 dan nilai simpangan regresi $\left(S_{d i}^{2}\right)$ mendekati 0 . Karakter hasil panen polong segar galur BBL 6.1.1 dan galur GSG 1.5 menunjukkan nilai koefisien regresi tidak sama dengan satu sehingga dikatakan tidak stabil, sedangkan galur GSG 2.5, GSG 2.1.1, CCC 1.4.1, dan PEBG 5.3.1 adalah galur yang stabil (Tabel 3).

Tabel 1. Deskripsi tempat penanaman kacang Bogor di tiga lokasi berbeda di Kab. Malang

\begin{tabular}{|c|c|c|c|c|c|c|c|c|c|}
\hline \multirow{2}{*}{$\begin{array}{c}\text { Lokasi/ } \\
\text { penanaman }\end{array}$} & \multirow{2}{*}{ Jenis lahan } & \multirow{2}{*}{$\begin{array}{l}\text { Ketinggian } \\
\text { (mdpl) }\end{array}$} & \multirow{2}{*}{ Jenis tanah } & \multirow{2}{*}{ Tekstur tanah } & \multirow{2}{*}{$\begin{array}{c}\mathrm{CH} \\
(\mathrm{mm})\end{array}$} & \multicolumn{2}{|c|}{ Suhu $\left({ }^{\circ} \mathrm{C}\right)$} & \multirow{2}{*}{$\begin{array}{l}\text { RH } \\
(\%)\end{array}$} & \multirow{2}{*}{$\begin{array}{l}\mathrm{BO} \\
(\%)\end{array}$} \\
\hline & & & & & & mak & $\min$ & & \\
\hline $\begin{array}{l}\text { Kromengan/ } \\
\text { Feb-Mei }\end{array}$ & tegal & 330 & Alluvial & $\begin{array}{l}\text { Lempung liat } \\
\text { berdebu }\end{array}$ & 1563,50 & 27,81 & 24,53 & 83 & 0,44 \\
\hline $\begin{array}{l}\text { Singosari/ } \\
\text { Mei-Sept }\end{array}$ & sawah & 436 & Latosol & Debu & 658,60 & 28,10 & 24,08 & 73 & 1,85 \\
\hline $\begin{array}{l}\text { Lawang/ } \\
\text { Juni- Okt }\end{array}$ & $\begin{array}{l}\text { sawah tadah } \\
\text { hujan }\end{array}$ & 602 & Latosol & $\begin{array}{l}\text { Lempung } \\
\text { berdebu }\end{array}$ & 721,60 & 28,38 & 24,70 & 72 & 2,05 \\
\hline
\end{tabular}

Keterangan: $\mathrm{CH}$ adalah curah hujan, $\mathrm{RH}$ adalah kelembaban, $\mathrm{BO}$ adalah bahan organik 
Tabel 2. Hasil analisis ragam gabungan untuk hasil panen polong segar dan hasil panen biji kering 6 galur kacang Bogor pada 3 lokasi

\begin{tabular}{lcrccccc}
\hline \multirow{2}{*}{$\begin{array}{c}\text { Sumber } \\
\text { Keragaman }\end{array}$} & $\mathrm{db}$ & \multicolumn{3}{c}{ Hasil panen polong segar } & \multicolumn{3}{c}{ Hasil panen biji kering } \\
\cline { 3 - 8 } & & $\mathrm{KT}$ & $\mathrm{F}$ hit & $\begin{array}{c}\text { Kontribusi } \\
\text { keragaman (\%) }\end{array}$ & $\mathrm{KT}$ & $\mathrm{F}$ hit & $\begin{array}{c}\text { Kontribusi } \\
\text { keragaman (\%) }\end{array}$ \\
\hline Ulg/Lingk & 6 & 1,45 & 1,63 & & 0,23 & 1,15 & \\
Lingk (L) & 2 & 11,90 & $13,37^{* *}$ & 30,63 & 16,45 & $82,25^{* *}$ & 51,54 \\
Genotipe (G) & 5 & 3,00 & $3,37^{* *}$ & 19,30 & 1,31 & $6,55^{* *}$ & 10,26 \\
Interaksi G x L & 10 & 0,35 & $0,39^{* *}$ & 34,36 & 1,70 & $8,50^{* *}$ & 26,63 \\
Galat & 30 & 0,89 & & & 0,20 & & \\
Total & 53 & 17,59 & & & 19,89 & & \\
\hline
\end{tabular}

Keterangan: $\mathrm{db}$ adalah derajat bebas, KT adalah kuadrat tengah, F hit adalah nilai F hitung

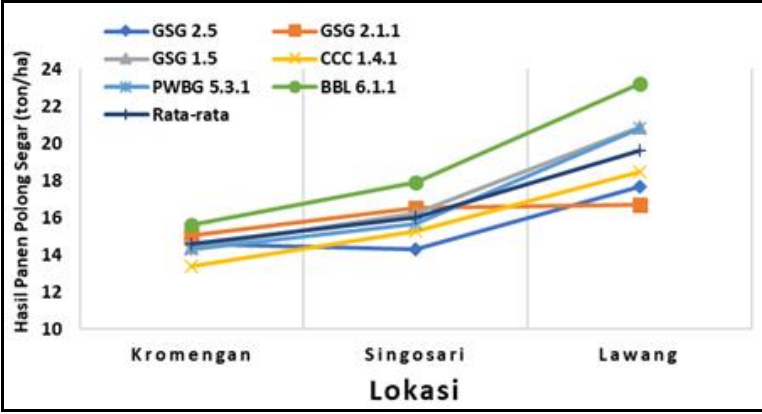

Gambar 1. Pola peringkat hasil panen polong segar 6 galur kacang Bogor di 3 lokasi

Koefisien regresi dari genotipe GSG 1.5 dan BBL 6.1.1 berbeda nyata dengan 1 dengan nilai koefisien regresi berbeda nyata lebih besar dari 1, yaitu berada di atas garis horizontal sehingga kedua genotipe tersebut adaptif pada lingkungan produktif (Gambar 3). Hasil uji regresi antara karakter hasil panen polong segar (ton ha-1) dengan indeks lokasi menunjukkan bahwa galur BBL 6.1.1 dan GSG 1.5 berada di atas garis rata- rata dibandingkan lima galur yang lainnya yang mengindikasikan bahwa galur tersebut memiliki responsibilitas tinggi sesuai dengan indeks lingkungan. Galur tersebut memiliki stabilitas di bawah rata-rata, sehingga memiliki kepekaan yang tinggi terhadap perubahan lingkungan dan dapat direkomendasikan ditanam di lahan produktif lokasi 3 (Lawang).

Hasil panen polong segar menandakan galur PWBG 5.3.1 adalah galur yang stabil dan berada di atas garis linier rata-rata yang mengindikasikan penampilan galur tersebut sesuai dengan perubahan indeks lingkungan dan beradaptasi baik pada seluruh lingkungan. Galur CCC 1.4.1, GSG2.5, serta GSG 2.1.1 adalah galur yang stabil namun memiliki nilai rata-rata berada di bawah garis linier rata-rata (Gambar 3). Hal ini mengindikasikan bahwa galur tersebut stabil dengan daya hasil yang rendah.

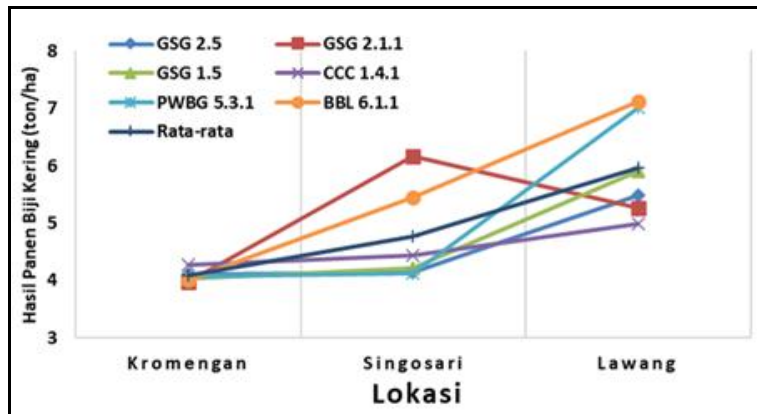

Gambar 2. Pola peringkat hasil panen biji kering 6 galur kacang Bogor di 3 lokasi

Hasil uji sampel tanah yang telah dilakukan di tiga lokasi mengindikasikan lokasi 3 memiliki bahan organik yang lebih tinggi dibandingkan lokasi lainnya. Bahan organik dapat meningkatkan panjang polong, jumlah polong, dan berat polong segar tanaman karena banyak mengandung unsur hara N, P, dan K yang dapat berperan dalam pembentukan dan pertambahan luas daun. Semakin tinggi residu bahan organik yang ada dalam tanah maka semakin banyak hara N, P, K yang diserap oleh tanaman (Safuan et al., 2012).

Hasil analisis stabilitas pada karakter hasil biji kering menunjukkan bahwa seluruh galur memiliki nilai koefisien regresi (bi) sama dengan satu dan ada galur yang mempunyai nilai simpangan dari regresi tidak sama dengan nol (Tabel 4). Hasil biji kering Galur BBL 6.1.1 berada di atas garis linier rata-rata dan memiliki koefisien regresi tidak berbeda nyata dengan satu serta simpangan terhadap regresi sama dengan nol. Hal ini mengindikasikan bahwa galur tersebut stabil dengan penampilan di atas rata-rata umum untuk karakter hasil biji kering. Galur GSG 2.5, GSG 1.5 dan CCC 1.4.1 adalah galur yang stabil namun penampilan rata-rata berada di bawah garis linier rata-rata umum (Gambar 4). Galur GSG 2.1.1 dan galur PEBG 5.3.1 memiliki nilai koefisien regresi tidak 
berbeda nyata dengan satu namun memiliki nilai $\mathrm{Sd}^{2}$ berbeda nyata dengan nol. Jika suatu galur memiliki nilai simpangan terhadap regresi tidak sama dengan nol, maka penampilan galur tersebut sulit diprediksi.

Pada lokasi 1, curah hujan masih tinggi ketika tanaman memasuki fase generatif, sementara pada lokasi 2 dan 3, fase pertumbuhan generatif telah memasuki musim kemarau. Seperti halnya kacang tanah, kacang Bogor memiliki polong yang berkembang di dalam tanah setelah penyerbukan. Kelembaban terlalu tinggi pada saat pengisian polong akan menurunkan hasil (Rahmianna et al., 2015). Tingginya curah hujan pada saat fase generatif menyebabkan hasil biji yang lebih kecil. Penelitian yang dilakukan di Ghana mendapatkan hasil bahwa produksi polong dan biji bervariasi antar genotipe berbeda dan musim berbeda. Hasil polong berkisar antara $600 \mathrm{~kg} \mathrm{ha}^{-1}$ sampai 5,5 ton ha-1, sementara hasil biji antara $420 \mathrm{~kg} \mathrm{ha}^{-1}$ hingga 3,8 ton ha-1 (Berchie et al., 2016). Lokasi 3 juga memiliki lebih banyak bahan organik dibanding-kan dengan dua lokasi lainnya. Hal ini yang menyebabkan respons penampilan berat biji kering kacang Bogor di lokasi 3 lebih unggul dibandingkan dengan dua lokasi lainnya. Pemberian bahan organik terbukti meningkatkan berat kering biji pada kedelai sebesar 66,5\% (Hanum, 2013).

Tabel 3. Stabilitas (Eberhart Russell) dan adaptabilitas (Finlay-Wilkinson) karakter hasil panen polong segar (ton ha-1) 6 galur kacang Bogor

\begin{tabular}{|c|c|c|c|c|c|c|}
\hline Galur & Rentang & Rerata & $\mathrm{bi}=1$ & $\mathrm{Sd}^{2}=0$ & Stabilitas & Adaptabilitas \\
\hline GSG 2.5 & $14,28-17,66$ & 15,50 & $0,67^{\text {tn }}$ & $0,63^{\text {tn }}$ & Stabil & $\mathrm{A}$ \\
\hline GSG 2.1.1 & $15,06-16,70$ & 16,09 & $0,27^{\mathrm{tn}}$ & $0,40^{\text {tn }}$ & Stabil & A \\
\hline GSG 1.5 & $14,38-20,88$ & 17,16 & $1,28^{*}$ & $-0,21^{\text {tn }}$ & Tidak Stabil & $\mathrm{A}+$ \\
\hline CCC 1.4 .1 & $13,39-18,45$ & 15,71 & $0,97^{\mathrm{tn}}$ & $-0,08^{\mathrm{tn}}$ & Stabil & A \\
\hline PWBG 5.3.1 & $14,31-20,82$ & 16,94 & $1,31^{\text {tn }}$ & $-0,07^{\text {tn }}$ & Stabil & A \\
\hline BBL 6.1.1 & $15,59-23,21$ & 18,90 & $1,49^{*}$ & $-0,20^{\text {tn }}$ & Tidak Stabil & $\mathrm{A}+$ \\
\hline Rata-rata & & 16,72 & & & & \\
\hline
\end{tabular}

Keterangan: $\mathrm{b}=$ koefisien regresi, $\mathrm{Sd}^{2}=$ simpangan regresi, ${ }^{*}=$ berbeda nyata dari 1 atau 0 , th $=$ tidak nyata $\mathrm{A}=$ Adaptasi luas pada seluruh lingkungan pengujian, $\mathrm{A}+=$ Adaptasi sempit pada lingkungan produktif

Tabel 4. Stabilitas dan adaptabilitas karakter hasil panen biji kering (ton ha-1) 6 galur kacang bogor menurut Eberhart-Russell dan Finlay-Wilkinson

\begin{tabular}{|c|c|c|c|c|c|c|}
\hline Galur & Rentang & Rerata & $\mathrm{bi}=1$ & $\mathrm{Sd}^{2}=0$ & Stabilitas & Adaptabilitas \\
\hline GSG 2.5 & $4,11-5,49$ & 4,58 & 0,78 & 0,07 & Stabil & $\mathrm{A}$ \\
\hline GSG 2.1.1 & $3,98-6,17$ & 5,14 & 0,51 & $1,87^{*}$ & Tidak dapat diprediksi & - \\
\hline GSG 1.5 & $4,03-5,90$ & 4,72 & 1,04 & 0,09 & Stabil & A \\
\hline CCC 1.4.1 & $4,27-4,99$ & 4,57 & 0,39 & $-0,06$ & Stabil & A \\
\hline PWBG 5.3.1 & $4,07-7,02$ & 5,07 & 1,66 & $0,58^{*}$ & Tidak dapat diprediksi & - \\
\hline BBL 6.1.1 & $4,02-7,13$ & 5,53 & 1,62 & 0,00 & Stabil & A \\
\hline
\end{tabular}

Reterangan: $\mathrm{b}=$ koefisien regresi, $\mathrm{Sd}^{2}=$ simpangan regresi, ${ }^{*}=$ berbeda nyata dari 1 atau $0, \mathrm{tn}=$ tidak nyata $\mathrm{A}=$ Adaptasi luas pada seluruh lingkungan pengujian, $\mathrm{A}+=$ Adaptasi sempit pada lingkungan produktif

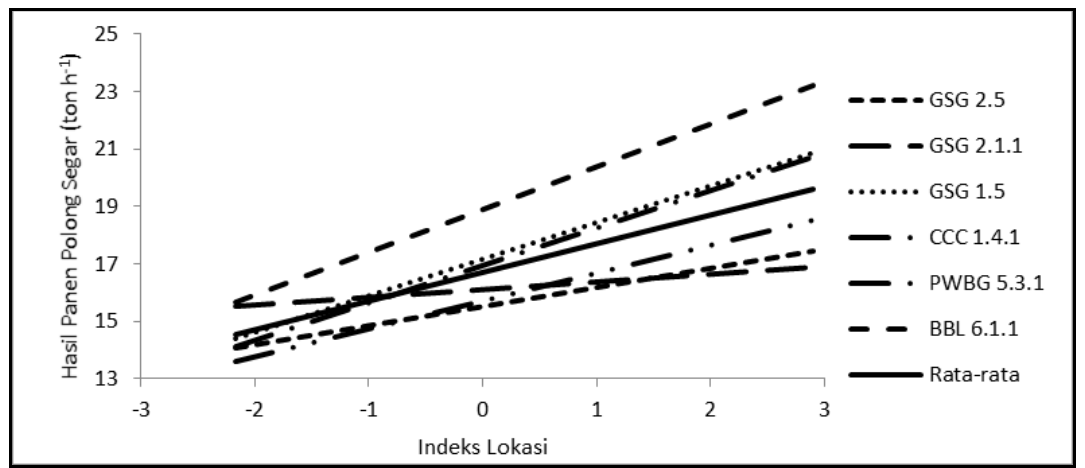

Gambar 3. Grafik Hubungan Linier Karakter Berat Polong Segar (ton ha-1) dengan Indeks Lokasi. 


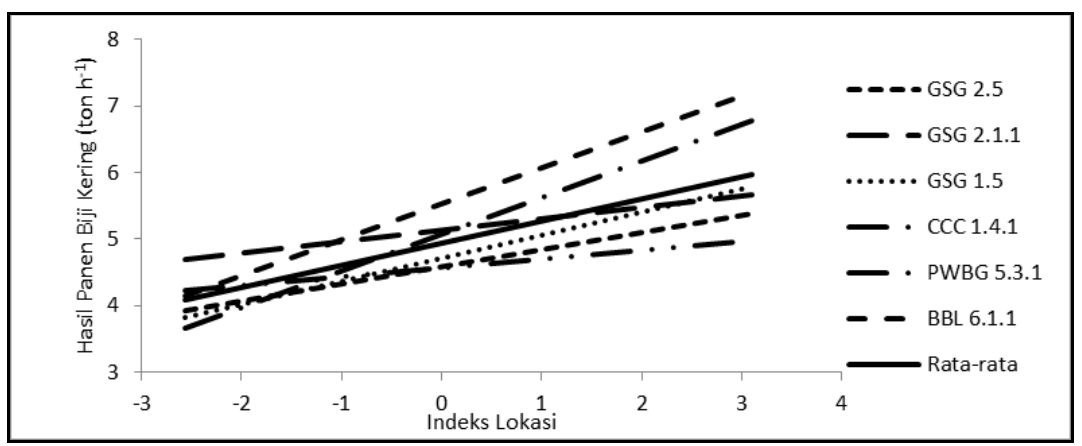

Gambar 4. Grafik Hubungan Linier Karakter Berat Biji Kering (ton.ha-1) dengan Indeks Lokasi.

Pada hasil pengujian stabilitas hasil terlihat bahwa setiap populasi galur harapan kacang Bogor mempunyai kemampuan adaptasi yang berbeda. Penyebab stabilitas hasil belum diketahui secara jelas tetapi diduga disebabkan adanya mekanisme penyangga individu dan penyangga populasi (Allard and Bradshaw, 1964). Populasi yang mempunyai komposisi genetik heterogen pada umumnya mempunyai kemampuan penyangga lebih besar daripada yang komposisi genetiknya homogen pada lokasi berbeda. Syukur et al. (2012) menjelaskan bahwa varietas beradaptasi dengan baik disebabkan varietas tersebut memiliki susunan gen atau kombinasi gen sedemikian sehingga mampu mempertahankan sifat morfologi maupun fisiologi yang dapat menyesuaikan diri pada lingkungan tertentu atau perubahan lingkungan. Hasil observasi Akande et al. (2009) menyebutkan bahwa penampilan galur yang stabil dengan daya hasil tinggi menunjukkan bahwa galur tersebut dapat ditanam pada rentang lingkungan budidaya yang luas.

\section{Kesimpulan}

Galur-galur yang diuji telah memiliki tingkat keseragaman yang tinggi. Galur BBL 6.1.1 adalah galur dengan umur panen yang lebih awal dengan potensi hasil tertinggi yang beradaptasi pada lingkungan produktif. Galur GSG 1.5 adalah galur yang hanya sesuai untuk ditanam pada lingkungan produktif. Galur PWBG 5.3.1 adalah galur yang stabil dan berproduksi tinggi. Galur GSG 2.5, 2.1.1, dan CCC 1.4.1 adalah galur yang stabil pada seluruh lingkungan dengan produktivitasnya relatif rendah.

\section{Ucapan Terima Kasih}

Terima kasih disampaikan kepada Kemenristek Dikti bantuan pembiayaan penelitian ini melalui skema hibah Penelitian Unggulan Perguruan Tinggi tahun 2016.

\section{Daftar Pustaka}

Adie, M.M., A. Krisnawati, and G. Susanto. 2013. Genotype $\times$ environment interactions, yield potential and stability of black soybean (Glycine max (L.) Merr) promising lines. Ber. Biol. 12(1): 79-86.

Akande, S.R., L.B. Taiwo, A.A. Adegbite, and O.F. Owolade. 2009. Genotype x environment interaction for soybean grain yield and other reproductive characters in the forest and savanna agro-ecologies of South-west Nigeria. African J. Plant Sci. 3(6): 127-132.

Akmal, A., C. Gunarsih, dan M.Y. Samaullah. 2015. Adaptasi dan stabilitas hasil galurgalur aromatik padi sawah di Sumatera Utara. J. Penelit. Pertan. Tanam. Pangan 33(1): 9. doi: 10.21082/jpptp.v33n1.2014.p916.

Allard, R.W., and A.D. Bradshaw. 1964. Implications of genotype- environmental interactions in applied plant breeding. Crop Sci. 4(5): 503-508. doi: 10.2135/ cropsci1964.0011183x000400050021x.

Annicchiarico, P. 2002. Genotype x environment interactions: challenges and opportunities for plant breeding and cultivar recommendations. Food and Agriculture Organization of The United Nations, Rome, Italy. 
Annicchiarico, P., F. Bellah, and T. Chiari. 2006. Repeatable genotype $x$ location interaction and its exploitation by conventional and GIS-based cultivar recommendation for durum wheat in Algeria. Eur. J. Agron. 24(1): 70-81. doi: 10.1016/j.eja.2005.05.003.

Arif, A., N. Kendarini, and Kuswanto. 2016. Evaluation of genetic purity on 20 genotypes of Bambara groundnut (Vigna subterranea L. Verdcourt) selected from single seed descent morphological character. J. Produksi Tanam. 4(3): 169-173. http://protan.studentjournal.ub.ac.id/inde x.php/protan/article/view/277/268.

Asad, M.A., H.R. Bughio, I.A. Odhano, M.A. Arain, and M.S. Bughio. 2009. Interactive effect of genotype and environment on the paddy yield in Sindh province. Pakistan J. Bot. 41(4): 1775-1779.

Baye, T.M., T. Abebe, and R.A. Wilke. 2011. Genotype-environment interactions and their translational implications. Per. Med. 8(1): 59-70. doi: 10.2217/ pme.10.75.

Becker, H., and J. Leon. 1988. Stability Analysis in Plant Breeding. Plant Breed. 101(1): 1-23. doi: 10.1111/j.1439-0523.1988.tb00261.x.

Berchie, J., H. Dapaah, A. Agyeman, J. SarkodieAddo, J. Addo, et al. 2016. Performance of five bambara groundnut (Vigna subterranea (L.) Verdc.) landraces in the trasition agroecology of Ghana under different sowing dates. Agric. Food Sci. J. Ghana 9: 718-729.

Chijioke, O.B., U.M. Ifeanyi, and A.C. Blessing. 2010. Pollen behaviour and fertililization impairment in Bambara groundnut (Vigna subterrenea [L.] Verdc.). J. Plant Breed. Crop Sci. 2(1): 12-23. http://international scholarsjournals.org/download.php?id=17 1100628520309740.pdf\&type $=$ application $/ \mathrm{p}$ df\&op $=1$.

Dolinassou, S., J.B.N. Tchiagam, A.D. Kemoral, and N.N. Yanou. 2016. Genotype × environment interaction and kernel yieldstability of groundnut (Arachis hypogaea L.) in Northern Cameroon. J. Appl. Biol. Biotechnol. 4(01): 1-7. doi: 10.7324/ jabb.2016.40101.

Eberhart, S.A., and W.A. Russell. 1966. Stability parameters for comparing varieties. Crop Sci. 6(1): 36-40. doi: 10.2135/cropsci1966. 0011183x000600010011x.

Farshadfar, E., M.M. Poursiahbidi, and M. Jasemi. 2012. Evaluation of phenotypic stability in bread wheat genotypes using GGE-biplot. Int. J. Agric. Crop Sci. 4(13): 904-910.

Finlay, K.W., and G.N. Wilkinson. 1963. The analysis of adaptation in a plant-breeding programme. Aust. J. Agric. Res. 14(6): 742754. doi: 10.1071/AR9630742.

Gomez, K.A., dan A.A. Gomez. 1995. Prosedur Statistik untuk Penelitian Pertanian. $2^{\text {nd }}$ ed. UI-Press, Jakarta.

Hanum, C. 2013. Pertumbuhan, hasil, dan mutu biji kedelai dengan pemberian pupuk organik dan Fosfor. J. Agron. Indones. 41(3): 209-214. doi: 10.24831/jai.v41i3.8098.

LeClerg, E.L., W.H. Leonard, and A.G. Clark. 1966. Field Plot Technique. 2nd ed. Burges Publishing Company, Minneapolis 23, Minnesota.

Mabhaudhi, T., and A.T. Modi. 2013. Growth, phenological and yield responses of a bambara groundnut (Vigna subterranea (L.) Verdc.) landrace to imposed water stress under field conditions. South African J. Plant Soil 30(2): 69-79. doi: 10.1080/02571862.2013.790492.

Muhammad, Y.Y., S. Mayes, and F. Massawe. 2016. Effects of short-Term water deficit stress on physiological characteristics of Bambara groundnut (Vigna subterranea (L.) Verdc.). South African J. Plant Soil 33(1): 51-58. doi: 10.1080/02571862.2015.1056847.

Nor, K.M., and F.B. Cady. 1979. Methodology for identifying wide adaptability in crops. Agron. J. 71: 556-559.

Nugraha, A.A., N.R. Ardiarini, dan Kuswanto. 2017. Uji keseragaman galur dan kekerabatan antar galur kacang Bogor (Vigna subterranea (L.) Verdc) hasil single seed descent kedua. J. Produksi Tanam. 5(7): 1196-1206.

Nuryati, A. Soegianto, and Kuswanto. 2014. Genetic relationship and variability among Indonesian purified local lines of bambara groundnut (Vigna subterranea (L.) Verdc.) based on morphological characters. African J. Sci. Res. (3): 18-24. http://ajsr. rstpublishers.com/.

Petersen, R.R. 1994. Agricultural Field Experiments: Design and Analysis. Marcel Dekker, Inc., New York-Basel-Hongkong.

Pratama, P., dan D. Saptadi. 2017. Uji daya hasil delapan galur harapan kacang Bogor (Vigna subterranea L. Verdcourt.) berdaya hasil tinggi. J. Produksi Tanam. 5(10): 1686- 
1691. http:// protan.studentjournal.ub. ac.id/index.php/protan/article/viewFile/ $558 / 561$.

Pungulani, L., D. Kadyampakeni, L. Nsapato, and M. Kachapila. 2012. Selection of high yielding and farmers' preferred genotypes of bambara Nut (Vigna subterranea (L.) Verdc) in Malawi. Am. J. Plant Sci. 03(12): 1802-1808. doi: 10.4236/ajps.2012.312a221.

Purwoko, B.S., D. Wirnas, and S. Dewi. 2014. Potensi dan stabilitas hasil, serta adaptabilitas galur-galur padi gogo tipe baru hasil kultur antera. J. Agron. Indones. 42(1): 9-16.

Rahayu, S., A.K. Dewi, Yulidar, D. Wirnas, dan H. Aswidinnoor. 2013. Analisis stabilitas dan adaptabilitas beberapa galur padi dataran tinggi hasil mutasi induksi. A Sci. J. Appl. Isot. Radiat. 9(2): 81-90.

Rahmawati, A., H. Purnamawati, dan Y.W.E. Kusumo. 2016. Pertumbuhan dan produksi kacang Bogor (Vigna subterranea (L.) Verdcourt) pada beberapa jarak tanam dan frekuensi pembumbunan. Bul. Agrohorti 4(3): 302.

Rahmianna, A.A., H. Pratiwi, dan D. Harnowo. 2015. Budidaya Kacang Tanah. dalam: Kasno, A., Rahmianna, A.A., Mejaya, I.M.J., Harnowo, D., dan Purnomo, S., editor.
Kacang Tanah, Inovasi Teknologi dan Pengembangan Produk. Balitkabi, Malang. p. 133-169

Sabaghnia, N., R. Karimizadeh, and M. Mohammadi. 2012. Genotype by environment interaction and stability analysis for grain yield of lentil genotypes. Zemdirbyste-Agriculture 99(3): 305-312.

Safuan, L.O., Buludin, dand N.W.S. Suliartini. 2012. Pengaruh residu bahan organik terhadap pertumbuhan dan poduksi tanaman kacang panjang (Vigna sinensis L.). J. Agroteknos 2(1): 1-8.

Schaafsma, G. 2012. Advantages and limitations of the protein digestibility-corrected amino acid score (PDCAAS) as a method for evaluating protein quality in human diets. Br. J. Nutr. 108(SUPPL. 2): 333-336. doi: 10.1017/S0007114512002541.

Syukur, M., S. Sujiprihati, dan R. Yunianti. 2012. Teknik Pemuliaan Tanaman. Penebar Swadaya, Bogor.

Yao, D.N., K.N. Kouassi, D. Erba, F. Scazzina, N. Pellegrini, et al. 2015. Nutritive evaluation of the Bambara groundnut Ci12 landrace [Vigna subterranea (L.) Verdc. (Fabaceae)] produced in Côte d'Ivoire. Int. J. Mol. Sci. 16(9): 21428-21441. doi: 10.3390/ ijms160921428. 